\title{
Assessement of Subtle Neurobehavioral Changes Induced By Potassium Nitrate In Rats And Theire Response Treatment By Ascorbic Acid
}

\author{
M. B. Mahmood \\ Department of Surgery \& Obstetric / College of Veterinary \\ Medicine University of Dohuk
}

Received

$r$ r $+r / 2009$

\author{
Accepted \\ $.0 / 05 / 2009$
}

\section{الخلاصة}

مُ ققيم التأثيرات للسلوكية العصبية الناتجة عن التجريع المستمر (مع العاف) به مادة

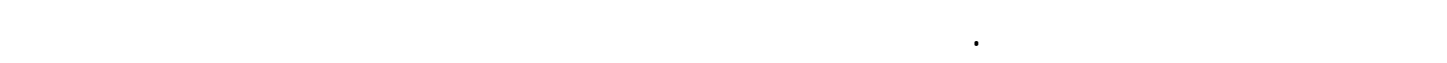

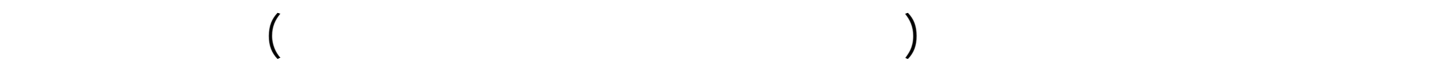

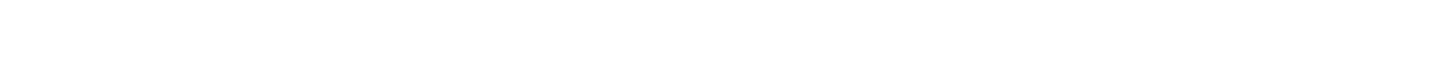

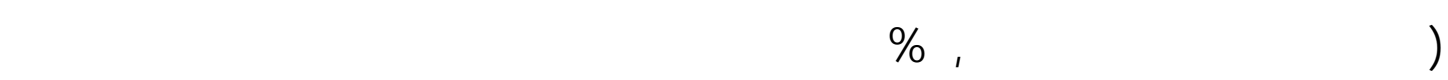

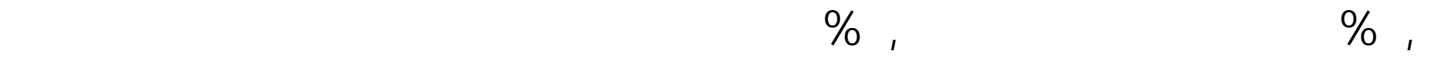

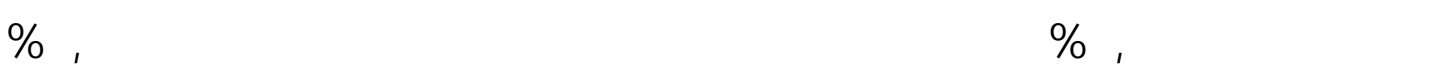

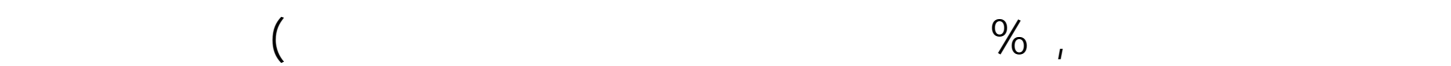

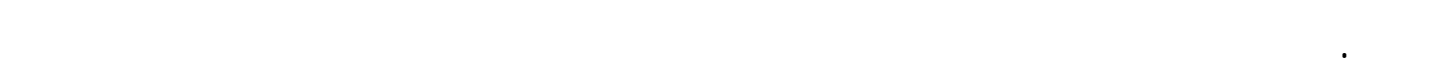

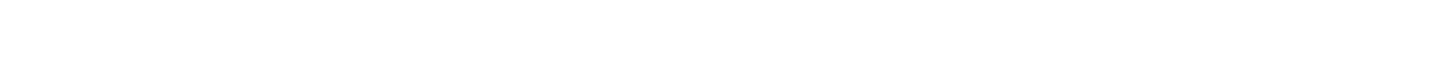

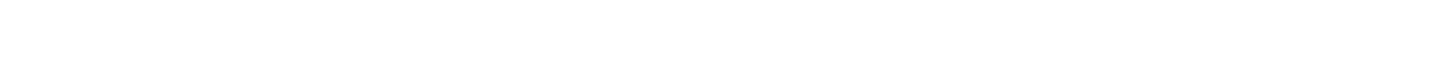

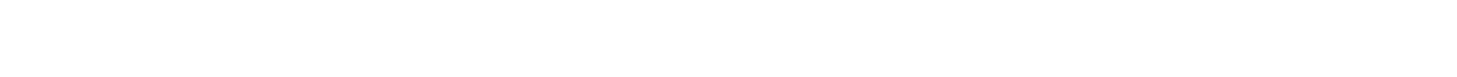

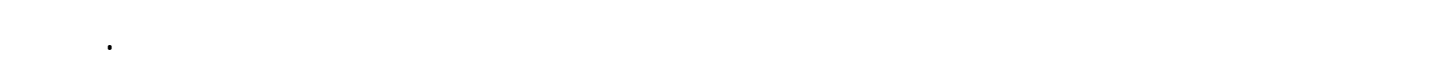

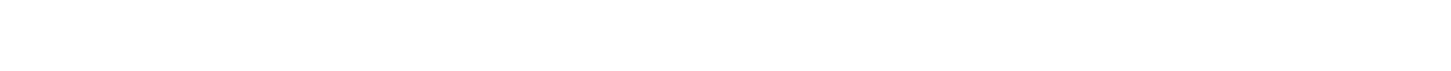

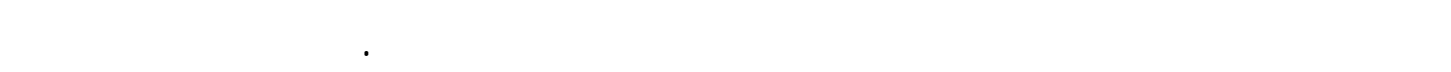

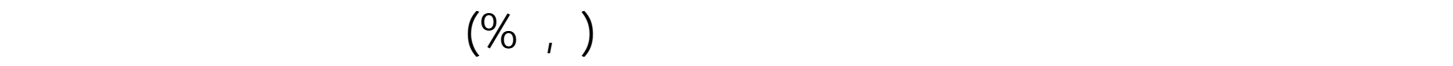

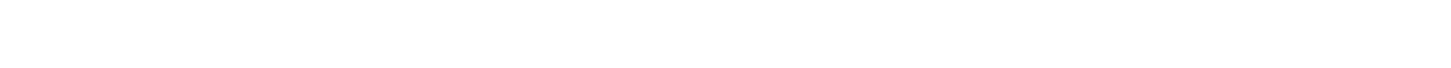

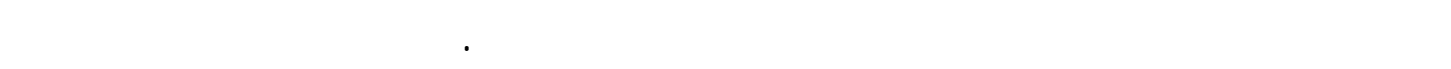

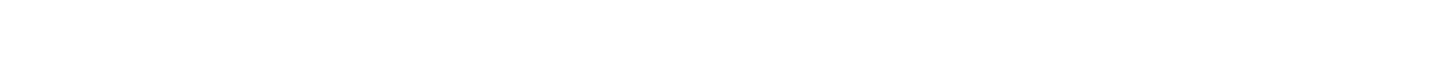
عصبية للكثف عن التغيرات السلوكية الجانبية والمحثة بولنطة النترات البوتلنيوم. 


\section{ABSTRACT}

The neurobehavioral effects of continuous dosing (as food additive) with potassium nitrate were assessed in albino rats. The rats were divided into the five groups, the control group have been fed in a concentrated forage (Barley, wheat, soybean, corn, wheatbrane) where as the treatment groups were fed with the same concentrated forage with the addition of potassium nitrate in different percentages (second group added $0.1 \%$, 3rd group added $0.1 \%$ with $0.2 \%$ ascorbic acid as antidote, 4 th group added $0.2 \%, 5^{\text {th }}$ group added $0.2 \%$ with $0.4 \%$ ascorbic acid as antidote) respectively for 5 weeks. Potassium nitrate did not produce overt signs of toxicosis but significantly decreased the open-field activity and also decreased the number of rearing during the open-field activity test, they reached to minimum level at the $4^{\text {th }}$ week of treatment were reported, these decrease were followed gradual elevation to reach that values of the control group level at the end of study period. Potassium nitrate significant delayed the negative geotaxis at $45^{\circ}$ angle and retain to reach the control level in $5^{\text {th }}$ week in .The treated rats also suffered from a gradual increase in the body weight in comparison with pretreatment values, where as there was no effective significant the number of fecal boluses and swimming endurance. In this study the ascorbic acid (as antidote) in group 5 ( $0.4 \%$ with $0.2 \%$ potassium nitrate) differed significantly with group $4(0.2 \%$ potassium nitrate only) that means the ascorbic acid give good result when it used for treatment of nitrate poisoning in animals. The results support the notion that in the absence of overt signs of toxicosis, neurobehavioral tests could be used to detect adverse behavioral changes induced by potassium nitrate.

\section{INTRODUCTION}

Nitrate intoxication induce complex and diverse neurobehavioral effects in man and different animal species and represent one of medical and veterinary problems nowadays (1). The intoxication is being diagnosed with increasing frequency as heavy fertilization with nitrogenous compounds becoming more widely used $(2,3)$. Various neurobehavioral tests are available to detect acute, subacute or subtle neurotoxicity of nitrate compounds as well as other neurotoxicants in laboratory animals $(4,5,6,7)$. These tests assess different functional aspects of the animals $(3,4,5,8,910)$ Automated motor activity measurement and functional observational batters of tests have been recently used to evaluate the neurotoxicity of nitrate compounds as well as other compounds like cholinesterase inhibitors (10). Rhaymah and Alkhafaji (6) have adapted several neurobehavioral tests (open-field activity, negative geotaxis, ataxia as well as food intake) to evaluate behavioral changes induced by nitrite intoxication in rats. In order to further expand and support such findings, the present study assessed the 
neurobehavioral effects of chronic exposure to non-overtly toxic dose of the nitrate compound in rats, and the ascorbic acid can affect them or not.

\section{MATERIALS AND METHODS}

The study was involved 35 rats of both sexes, their body weights ranged between (91.7-155.7 g) and their ages between (2-3) months. They were divided in to five equal groups each group $(n=7)$; they were housed at a room temperature with $10 \backslash 14$ light—dark cycle. Animals of the first group were left as a control group and have been fed concentrated forage (Barley, wheat, soybean, corn, wheatbrane) where as the treated groups were fed the same concentration forage with the addition of potassium nitrate (Gerhard Buchman Tuttingeen Germany) in different concentrations ( $2^{\text {nd }}$ group $0.1 \%$, 3rd group a $0.1 \%$ with $0.2 \%$ ascorbic acid as antidote, $4^{\text {th }}$ group $0.2 \%$, 5 th group $0.2 \%$ with $0.4 \%$ ascorbic acid as antidote) respectively for five weeks. These doses of potassium nitrate did not cause overt signs of toxicosis in rats (6).

Animal behavior was recorded on the $1^{\text {st }}$ day weekly during the experimental period. The general behavior tests included: 3 -minute open-field activity (general locomotors activity) including the counting of the squares crossed and rearing in a $90 \times 60 \times 30 \mathrm{~cm}$ box divided in to 24 equal squares (11), negative geotaxis test was performed by placing the rat in ahead down position on the inclined surface at angle of $45^{\circ}$, and the time needed (maximum 60 seconds) to complete $180^{\circ}$ turn was measured (12). Swimming endurance estimates the movement activity of the animal and its neuromuscular balance (5), the animals was placed on abanio of $46 \mathrm{~cm}$ diameter $46 \mathrm{~cm}$ depth contain water of $22-24 \mathrm{C}^{\circ}$, the time of keeping the head under water for a period up to 10 seconds was depended in this test. The tests also include measurement of body weights were conducted on day 0 (pretreatment day -base line value) and there after during the treatment period on $1^{\text {st }}$ day weekly for 5 consecutive weeks. All tests were conducted between 9 - 12 A.M. The data were subjected to analysis of variance followed by the least significant difference test (13). The number of fecal boluses were statistically analyzed by the Mann -Whitney - U - test and the measurement of body weight were statistically analyzed by repeated measurement analyzed of variance (14), the level of significant was at $\mathrm{P}<0.05$.

\section{RESULTS}

Potassium nitrate in concentrations of (o.1\% and $0.2 \%)$ did not produce overt signs of intoxication, but caused significant decrease in number of squares crossed in the concentration group of $0.1 \%$ and $0.2 \%$ at $4^{\text {th }}$ week in comparison with the value of control group (Table 1), and the values in $0.2 \%$ (4 group) in comparison with the values in $0.1 \%$ (group 2) and decreased significantly in $2^{\text {nd }}, 3^{\text {rd }}$ and $4^{\text {th }}$ weeks comparison 
with the values at time 0 (table 1), and significantly increased in the group 4 in $5^{\text {th }}$ week comparison with values in same group in $2^{\text {nd }}, 3^{\text {rd }}$ and $4^{\text {th }}$ weeks also increased significantly in group 5 in comparison with group 4 in $2^{\text {nd }}, 3^{\text {rd }}$ and $4^{\text {th }}$ weeks (table1). However, habituation to the open-field activity test was noted in group4 (0.2\%).

Potassium nitrate only in a concentration $0.2 \%$ (group 4) lead significantly decreased of rearing in $2^{\text {nd }}, 3^{\text {rd }}$ and $4^{\text {th }}$ weeks in comparison with the control value, and also significant decreased comparison with time 0 and with dose $0.1 \%$ (group 2), also a significant increased of group (5) in comparison with group (4) in $2^{\text {nd }}, 3^{\text {rd }}$ and $4^{\text {th }}$ weeks and increased significantly value of $5^{\text {th }}$ week in comparison with the $3^{\text {rd }}$ and $4^{\text {th }}$ weeks in group 4 (Table 2).

The result of the present study showed significant increased of negative geotaxis values in $3^{\text {rd }}$ and $4^{\text {th }}$ weeks in group 4 comparison with the control values, also it led to a significant increased in comparison with the value of group (5), also in group 4 caused in $4^{\text {th }}$ week increased significantly comparison with pre treatment and $5^{\text {th }}$ week.(table 3 )

The result of body weight test manifested the potassium nitrate at different doses led to a significant increased of values in comparison with those of pretreatment values. Also in the dose $0.2 \%$ (group 4 ) it caused increase significantly in comparison with the dose $0.2 \%$ mixed with ascorbic acid $0.4 \%$ (group 5) ( table 4).

The result of present study revealed the potassium nitrate did not significantly affected to the fecal boluses and swimming endurance.

Table 1: The effect of potassium nitrate on the open -field in rats

\begin{tabular}{|c|c|c|c|c|c|c|}
\hline \multirow{2}{*}{$\begin{array}{c}\text { Concentration } \\
\text { (\%) as food } \\
\text { additive }\end{array}$} & \multicolumn{5}{|c|}{ Squires Crosse / weeks } \\
\cline { 2 - 7 } & $\mathbf{0}$ & $\mathbf{1}$ & $\mathbf{2}$ & $\mathbf{3}$ & $\mathbf{4}$ & $\mathbf{5}$ \\
\hline $\mathbf{0}$ & $54.8 \pm 3.11$ & $56.5 \pm 1.49$ & $56.5 \pm 3.69$ & $56.1 \pm 2.38$ & $57.4 \pm 8.60$ & $57.5 \pm 6.89$ \\
\hline $\mathbf{0 . 1 \%}$ & $53.5 \pm 2.23$ & $52.4 \pm 2.39$ & $49.7 \pm 3.89$ & $50.2 \pm 3.79$ & $\begin{array}{c}+ \\
44.0 \pm 3.11\end{array}$ & $53.4 \pm 5.99$ \\
\hline $\begin{array}{c}\mathbf{0 . 1 \%} \text { with } \\
\text { ascorbic acid } \\
\mathbf{0 . 2 \%}\end{array}$ & $59.2 \pm 3.58$ & $58.2 \pm 2.85$ & $60.2 \pm 1.32$ & $60.0 \pm 3.86$ & $\begin{array}{c}\mathbf{a} \\
59.0 \pm 5.24\end{array}$ & $58.8 \pm 4.10$ \\
\hline $\begin{array}{c}\mathbf{0 . 2 \%} \\
\mathbf{0 . 2 \%} \text { with } \\
\text { ascorbic acid } \\
\mathbf{0 . 4 \%}\end{array}$ & $59.8 \pm 3.27$ & $58.4 \pm 4.19$ & $61.4 \pm 1.91$ & $63.4 \pm 6.53$ & $61.7 \pm 3.80$ & $59.1 \pm 3.98$ \\
\hline
\end{tabular}

Significant with day $(0) \mathrm{P}<0.05$

Significant with concentration 0 (control.) $\mathrm{P}<0.05$

Significant with $(0.1 \%) \mathrm{P}<0.05$

Significant with $(0.2 \%) \mathrm{P}<0.05$

Significant with week (4) $\mathrm{P}<0.05$ 
Table 2: The effect of potassium nitrate on rearing in rats

\begin{tabular}{|c|c|c|c|c|c|c|}
\hline \multirow{2}{*}{$\begin{array}{l}\text { Concentration } \\
(\%) \text { as food } \\
\text { additive }\end{array}$} & \multicolumn{6}{|c|}{ Rearing / week } \\
\hline & $\mathbf{0}$ & 1 & 2 & 3 & 4 & 5 \\
\hline $\mathbf{0}$ & $14.85 \pm 1.58$ & $15.0 \pm 1.05$ & $14.2 \pm 0.74$ & $13.8 \pm 0.55$ & $14.0 \pm 1.39$ & $13.2 \pm 0.99$ \\
\hline $0.1 \%$ & $14.1 \pm 1.26$ & $12.8 \pm 0.63$ & $12.4 \pm 0.78$ & $10.8 \pm 0.63$ & $11.4 \pm 0.86$ & $12.8 \pm 0.80$ \\
\hline $\begin{array}{c}0.1 \% \text { with ascorbic } \\
\text { acid } 0.2 \%\end{array}$ & $14.4 \pm 0.71$ & $13.7 \pm 2.38$ & $13.8 \pm 0.70$ & $12.2 \pm 1.76$ & $12.1 \pm 0.50$ & $13.0 \pm 1.44$ \\
\hline $0.2 \%$ & $14.2 \pm 0.47$ & $\begin{array}{c}+ \\
11.1 \pm 0.55\end{array}$ & $\begin{array}{c}*+ \\
10.5 \pm 0.57\end{array}$ & $\begin{array}{c}*+\mathbf{a} \\
4.7 \pm 1.20\end{array}$ & $\begin{array}{c}*+\mathbf{a} \\
4.14 \pm 1.56\end{array}$ & $\underset{11.1 \pm 0.63}{\text { c }}$ \\
\hline $\begin{array}{l}0.2 \% \text { with ascorbic } \\
\text { acid } 0.4 \%\end{array}$ & $14.4 \pm 1.37$ & $13.2 \pm 1.26$ & $\begin{array}{c}\mathbf{b} \\
14.2 \pm 1.20\end{array}$ & $\begin{array}{c}\mathbf{b} \\
13.5 \pm 1.08\end{array}$ & $\begin{array}{c}\mathbf{b} \\
13.4 \pm 1.11\end{array}$ & $13.2 \pm 0.52$ \\
\hline
\end{tabular}

* $\quad$ Significant with day (0) $\mathrm{P}<0.05$

$+\quad$ Significant with concentration 0 (control.) $\mathrm{P}<0.05$

a Significant with $(0.1 \%) \mathrm{P}<0.05$

b Significant with ( $0.2 \%) \mathrm{P}<0.05$

c Significant with week (4) $\mathrm{P}<0.05$

Table 3: The effect of potassium nitrate on negative geotaxis in rats

\begin{tabular}{|c|c|c|c|c|c|c|}
\hline \multirow{2}{*}{$\begin{array}{l}\text { Concentration } \\
(\%) \text { as food } \\
\text { addative }\end{array}$} & \multicolumn{6}{|c|}{ Geotaxis value / weeks } \\
\hline & $\mathbf{0}$ & 1 & 2 & 3 & 4 & 5 \\
\hline $\mathbf{0}$ & $5.2 \pm 0.99$ & $4.8 \pm 1.10$ & $5.4 \pm 1.52$ & $4.8 \pm 1.14$ & $5.0 \pm 2.02$ & $5.5 \pm 1.61$ \\
\hline $0.1 \%$ & $5.1 \pm 0.55$ & $5.1 \pm 1.41$ & $5.8 \pm 1.20$ & $6.8 \pm 1.76$ & $8.4 \pm 1.17$ & $6.4 \pm 1.40$ \\
\hline $\begin{array}{c}0.1 \% \text { with } \\
\text { ascorbic acid } \\
0.2 \% \\
\end{array}$ & $5.2 \pm 0.61$ & $4.8 \pm 0.76$ & $5.2 \pm 2.10$ & $4.8 \pm 1.34$ & $4.7 \pm 0.52$ & $5.5 \pm 0.71$ \\
\hline $0.2 \%$ & $6.1 \pm 0.73$ & $6.5 \pm 2.20$ & $7.1 \pm 1.79$ & $\begin{array}{c}+ \\
9.4 \pm 2.02\end{array}$ & $\begin{array}{c}*+ \\
11.0 \pm 2.6\end{array}$ & $\begin{array}{c}\text { c } \\
7.4 \pm 1.49\end{array}$ \\
\hline $\begin{array}{c}0.2 \% \text { with } \\
\text { ascorbic acid } \\
0.4 \% \\
\end{array}$ & $5.1 \pm 1.21$ & $5.1 \pm 1.42$ & $5.4 \pm 1.25$ & $\begin{array}{c}\mathbf{b} \\
5.1 \pm 1.22\end{array}$ & $\begin{array}{c}\mathbf{b} \\
5.2 \pm 1.22\end{array}$ & $5.4 \pm 1.63$ \\
\hline
\end{tabular}

* $\quad$ Significant with day (0) $\mathrm{P}<0.05$

$+\quad$ Significant with concentration 0 (control.) $\mathrm{P}<0.05$

b Significant with ( $0.2 \%) \mathrm{P}<0.05$

c Significant with week (4) $\mathrm{P}<0.05$ 
Table 4: The effect of potassium nitrate on body weight in rats

\begin{tabular}{|c|c|c|c|c|c|c|}
\hline \multirow{2}{*}{$\begin{array}{l}\text { Concentration } \\
(\%) \text { as food } \\
\text { additive }\end{array}$} & \multicolumn{6}{|c|}{ Body weight (gm) / weeks } \\
\hline & $\mathbf{0}$ & 1 & 2 & 3 & 4 & 5 \\
\hline $\mathbf{0}$ & $101.5 \pm 8.16$ & $\begin{array}{c}* * \\
123.0 \pm .72\end{array}$ & $\begin{array}{c}* \\
133.8 \pm 7.44\end{array}$ & $\begin{array}{c}* \\
143.8 \pm .82\end{array}$ & $\begin{array}{c}* \\
154.0 \pm 6.71\end{array}$ & $\begin{array}{c}* \\
166.8 \pm 5.40\end{array}$ \\
\hline $0.1 \%$ & $91.7 \pm 2.91$ & $\begin{array}{c}*_{+} \\
103.1 \pm .77\end{array}$ & $\begin{array}{c}* \\
124.5 \pm 3.87\end{array}$ & $\begin{array}{c}* \\
141.5 \pm 3.79\end{array}$ & $\begin{array}{c}* \\
154.2 \pm 2.97\end{array}$ & $\begin{array}{c}* \\
165.4 \pm 4.38\end{array}$ \\
\hline $\begin{array}{c}0.1 \% \text { with } \\
\text { ascorbic acid } \\
0.2 \% \\
\end{array}$ & $92.4 \pm 4.17$ & $\begin{array}{c}* \\
124.7 \pm .45\end{array}$ & $\begin{array}{c}* \\
138.1 \pm 3.13\end{array}$ & $\begin{array}{c}* \\
145.5 \pm 3.51\end{array}$ & $\begin{array}{c}* \\
159.4 \pm 7.92\end{array}$ & $\begin{array}{c}* \\
167.4 \pm 7.15\end{array}$ \\
\hline $0.2 \%$ & $92.5 \pm 5.02$ & $\begin{array}{c}* \\
125.1 \pm .96\end{array}$ & $\begin{array}{c}* \\
139.2 \pm 7.08\end{array}$ & $\begin{array}{c}* \\
141.7 \pm 6.10\end{array}$ & $\begin{array}{c}* \\
148.2 \pm 9.09\end{array}$ & $\begin{array}{c}* \\
161.1 \pm 8.35\end{array}$ \\
\hline $\begin{array}{c}0.2 \% \text { with } \\
\text { ascorbic acid } \\
0.4 \%\end{array}$ & $155.7 \pm 6.58$ & $\begin{array}{c}+\mathbf{b} \\
163.5 \pm 3.48\end{array}$ & $\begin{array}{c}*+\mathbf{b} \\
174.7 \pm 7.04\end{array}$ & $\begin{array}{c}*+\mathbf{b} \\
181.8 \pm 4.11\end{array}$ & $\begin{array}{c}*+\mathbf{b} \\
187.8 \pm 3.66\end{array}$ & $\begin{array}{c}*+\mathbf{b} \\
196.1 \pm .28\end{array}$ \\
\hline
\end{tabular}

* $\quad$ Significant with day (0) $\mathrm{P}<0.05$

$+\quad$ Significant with concentration 0 (control.) $\mathrm{P}<0.05$

b Significant with $(0.2 \%+$ ascorbic acid $0.4 \%) \mathrm{P}<0.05$

\section{DISCUSSION}

The main findings of the present study was that the continuous dosing (as food additive) with potassium nitrate caused behavioral alteration in rats. These effects reflect the general locomotors such as open-field activity, emotionality and intestinal transit as fecal boluses, neuromotor performance and coordination as negative geotaxis as previously reported by $(4,9,12)$. These findings further support speculation that nitrate compound induce diverse behavioral changes in the laboratory animals (6) that could be monitored by a battery of neurobehavioral tests assessing different functional aspects of the animals $(5,6,8,9)$. Habituation to open-field activity test is expected in rodents $(10,15)$.However, habituation in the present study was not a determinal factor to alter the overall conclusion that nitrate decreases the open-field activity and negative geotaxis in rats.

The neurobehavioral effects of nitrate were manifested clear in $4^{\text {th }}$ week of treatment in a concentration $0.2 \%$ and gradually retrain in $5^{\text {th }}$ week in time 0 value (pretreatment) that mean the animal had habituated to nitrate because same level feeding to potassium nitrate during long period (16).

The results of the present study referred that ascorbic acid in $0.4 \%$ was the best treatment in comparison with $0.2 \%$, furthermore it manifested to increase body weights during all periods of study due to 
gave all groups good concentrated forage, In $4^{\text {th }}$ group $(0.2 \%) \mathrm{a}$ significant increasment was seen in time 0 value because adding nitrogenous compound (nitrate $\mathrm{NH}_{3}$ ) to forage for along period. The result of present study revealed the potassium nitrate did not significantly affected to the fecal boluses and swimming endurance. Although the rats of the present study did not manifest overt signs of acute nitrate intoxicosis, the tests were sensitive enough to detect behavioral changes during the course of the exposure for early detection of subtle toxic effect of nitrate compounds (the animal appears apparently healthy) $(7,8,9)$.

\section{REFERENCES}

1) Chemlnitskii GA. Pathogenesis, diagnosis, treatment and prophylaxis of large ruminant poison with carbamade and nitrate. Ph.D. Thesis, Kiev, USSR.1979: 238.

2) Muslih NJ. Clinico-electrophonocardiograpgical and immunebiological changes in nitrate-nitrite toxicosis in sheep with and without treatment. PhD. Thesis, Stavropol Agri Institute, USSR 1991.

3) Blood DC. Radostitis OM. A text book of the diseases of cattle, sheep, goats, horses. $7^{\text {th }}$ ed. London: Bailliere Tindal, 1989:1279 1282.

4) Moinengo L, Fundaro A, Oresetti $M$. the effect of chronic atropine administration On mouse motility and on Ach.leveles in the central nervous system. Pharmacol Biochem Behav 1989; 32:1075 -1077.

5) Mohammad FK. Assessment of behavioral, Neurochmical and developmental effects in rats following in utero exposure to nonteratogenic levels of 2,4 -D $\backslash 2,4,5-\mathrm{T}$ Ph. D. Disseration, University of Missouri; Columbia, USA, 1984.

6) Rhaymah MS., AL-Khafaji NJ. Changes in rat behavior induced by nitrite Intoxication. Iraqi J Vet .Sci. 1999; 12:21 -28.

7) Faris G A-M, Mohammad FK. Assessment of subtle neurobehavioral changes Induced by dichlorvos in mice. Iraqi J Vet. Sci. 1998; 11:129 -138.

8) Karczmar AG. Acute and long lasting central action of organ phosphorous agent. Fund Appl Toxicol 1984; 4:237 -242.

9) koub LK, Mohammad FK Organ phosphorous diazinon-induced behavioral Changes in mice. Iraqi J Vet sci 1996; 9: 15 -19. 
10) Cory-Slechta DA. behavioral measures of neurotoxicity. Neurotoxicology 1989; 10:271-296.

11) McDaniel KL, Moser VC. Utility of neurobehavioral screening battery for differentiating the effects of two pyrethyoids, permethrin and Cypermethrin. Neurotoxicol teratol 1993; 15: 71 -83.

12) Mohammad FK, St Omer VEV. Behavioral and developmental effects in rats Following in utero exposure to 2, $4-\mathrm{D} \backslash 2,4,5-\mathrm{T}$ mixture. Neurobehav Toxicol Teratol 1986; 8: 551 -560.

13) Steel RG, Torrie JH: Principles and procedures of statistic. New York: McGram-Hill Book co, Inc, 1960:106.

14) Runyon RP: Nonparametric statistics. Reading, Massachusetts: Addison -Wesley Publishing Co, 1977. 42.

15) Moser VC. Utility of activity and observation data for neurotoxicity screening. In: Weiss B, o Donoghue J (eds). Neurobehavioral toxicity: analysis and Interpretation. New York: Raven Press, 1994:145 -152.

16) Hassan MG. Haematology, chemo-clinical and histological changes induced by chronic nitrate intoxication on sheep. Msc Thesis, University of mosul, mosul, Iraq 1991. 